\title{
Evaluation of metal contamination and phytoremediation potential of aquatic macrophytes of East Kolkata Wetlands, India
}

\author{
Amina Khatun ${ }^{1}$, Sandipan Pal ${ }^{2}$, Aloke Kumar Mukherjee ${ }^{3}$, Palas Samanta ${ }^{1,4}$, Subinoy Mondal ${ }^{1}$, \\ Debraj Kole ${ }^{1}$, Priyanka Chandra ${ }^{1}$, Apurba Ratan Ghosh ${ }^{1}$ \\ ${ }^{1}$ Department of Environmental Science, University of Burdwan, Burdwan; ${ }^{2}$ Department of Environmental Science, \\ Aghorekamini Prakashchandra Mahavidyalaya, Hooghly; ${ }^{3}$ Department of Conservation Biology, Durgapur Government \\ College, Durgapur, India; ${ }^{4}$ Division of Environmental Science and Ecological Engineering, Korea University, Seoul, Korea
}

\begin{abstract}
Objectives The present study analyzes metal contamination in sediment of the East Kolkata Wetlands, a Ramsar site, which is receiving a huge amount of domestic and industrial wastewater from surrounding areas. The subsequent uptake and accumulation of metals in different macrophytes are also examined in regard to their phytoremediation potential.

Methods Metals like cadmium (Cd), copper (Cu), manganese (Mn), and lead (Pb) were estimated in sediment, water and different parts of the macrophytes Colocasia esculenta and Scirpus articulatus.

Results The concentration of metals in sediment were, from highest to lowest, $\mathrm{Mn}$ $(205.0 \pm 65.5 \mathrm{mg} / \mathrm{kg})>\mathrm{Cu}(29.9 \pm 10.2 \mathrm{mg} / \mathrm{kg})>\mathrm{Pb}(22.7 \pm 10.3 \mathrm{mg} / \mathrm{kg})>\mathrm{Cd}(3.7 \pm 2.2 \mathrm{mg} /$ $\mathrm{kg})$. The phytoaccumulation tendency of these metals showed similar trends in both native aquatic macrophyte species. The rate of accumulation of metals in roots was higher than in shoots. There were strong positive correlations $(p<0.001)$ between soil organic carbon (OC) percentage and $\mathrm{Mn}(\mathrm{r}=0.771)$, and sediment $\mathrm{OC}$ percentage and $\mathrm{Pb}$ $(r=0.832)$. Cation exchange capacity (CEC) also showed a positive correlation $(p<0.001)$ with $\mathrm{Cu}(\mathrm{r}=0.721), \mathrm{Mn}(\mathrm{r}=0.713)$, and $\mathrm{Pb}(\mathrm{r}=0.788)$, while correlations between sediment OC percentage and $\mathrm{Cu}(r=0.628)$, sediment $\mathrm{OC}$ percentage and $\mathrm{Cd}(r=0.559)$, and CEC and $\mathrm{Cd}(r=0.625)$ were significant at the $p<0.05$ level.

Conclusions Bioaccumulation factor and translocation factors of these two plants revealed that $S$. articulatus was comparatively more efficient for phytoremediation, whereas phytostabilization potential was higher in C. esculenta.
\end{abstract}

Keywords: East Kolkata Wetlands, Metals, Phytoremediation, Colocasia esculenta, Scirpus articulatus
Correspondence: Apurba Ratan Ghosh Golapbag, Burdwan 713104, West Bengal, India

Tel: $+91-3422657938$

Fax: $+91-3422657938$

E-mail: apurbaghosh2010@gmail.com

Received: June 22, 2016

Accepted: September 8, 2016

Published: September 8, 2016

This article is available from: http://e-eht.org/

\section{Introduction}

Metal pollution has become a serious environmental threat since the Industrial Revolution. Wastewater from fertilizer, pesticide, cement, electroplating, painting, ceramics, battery, plastic, mining, and smelting industries are the major sources of metal contamination in aquatic environments. Domestic and municipal wastewater also contribute large amounts of different metals to the surrounding aquatic environment [1-4]. Essential metals such as iron, copper $(\mathrm{Cu})$, manganese $(\mathrm{Mn})$ and zinc $(\mathrm{Zn})$ play an important role in biological systems, whereas some non-essential metals like cadmium $(\mathrm{Cd})$, lead $(\mathrm{Pb})$ and mercury are consid- 
ered toxic even at low concentrations [5]. Essential metals also become toxic when they are present in higher concentrations for a longer period of time $[6,7]$.

Wetlands, the common receivers of wastewater both from industrial and domestic areas, act as a natural filter, sink and transformation system for pollutants [8]. They perform numerous valuable functions like nutrient recycling and carbon sequestration, and they harbor large biodiversity [9]. However, for the last few decades, the deleterious impacts on wetland ecosystems due to anthropogenic activities have been increasing. East Kolkata (previously Calcutta) Wetlands (EKW), an important Ramsar site, is receiving a huge amount of industrial and municipal discharge from Kolkata Metropolitan area every day.

Phytoremediation is a natural, cost-effective and eco-friendly process in which plants reduce the contamination of a site $[10,11]$. In the case of metal pollution, some plants can remove the toxic metals from soil, sediments or water by accumulating them in their harvestable part (above ground biomass), whereas other plants can immobilize metals in soil or sediment by forming a zone surrounding their roots, preventing the metals from leaching into groundwater $[12,13]$. There have been reports on metal concentrations in water $[14,15]$, soil $[3,14,16]$, plants $[3,14]$ and animals $[14,17-20]$, but research into phytoremediation by native plants in this wetland (EKW) is scarce. The present study examines the concentration of $\mathrm{Cd}, \mathrm{Cu}, \mathrm{Mn}$, and $\mathrm{Pb}$ in sediment of the EKW, and the possible phytoremediation of these metals by two native aquatic macrophyte species, Colocasia esculenta and Scirpus articulatus, based on two indices: transfer factor (TF) and bioaccumulation factor (BCF).

\section{Materials and Methods}

\section{Description of Study Site}

The EKW is situated in the eastern part of Kolkata city, India. They occupy a total area of about $125 \mathrm{~km}^{2}$ and serve as a 'Natural Kidney' for Kolkata, whereby they are used to treat the huge amount of wastewater runoff from the city as well as nearby industries. This area's economy relies on agriculture and sewagefed fisheries, and there are about 286 wastewater settling tanks used for fish culture [21]. Two native, aquatic, rooted macrophyte species (C. esculenta and S. articulatus) are dominant in this area and were selected for this study in order to investigate their bioaccumulation and phytoremediation potential.

\section{Sample Preparation and Analysis}

Thirteen different locations in the experimental site, the EKW was chosen (Figure 1). Samples of water, sediment and plants were collected in triplicate following the standard procedure of the American Public Health Association (APHA) [22]. Water samples were collected in acid treated polyvinyl containers and transported on ice-box to the laboratory, then stored at $4^{\circ} \mathrm{C}$ until analysis. A grab sampling method was used for collecting the water samples in plastic containers, which were rinsed with sample water three times. Water $\mathrm{pH}$ and electrical conductivity (EC) of the samples were measured using a multi-parameter tester (PCSTestr 35, Eutech Instruments, Singapore) in the field. For the metal analysis, $1 \mathrm{~L}$ of the water sample was acid-digested with nitric acid $\left(\mathrm{HNO}_{3}\right)$-perchloric acid $\left(\mathrm{HClO}_{4}\right)$ following the standard procedure of APHA [22].

Sediment samples were collected from a depth of 0-20 cm. Surface and layered samples were collected randomly in two batches and then mixed for each site, before packing them in polythene bags. After reaching the laboratory, sediment samples were air-dried at room temperature and then sieved using a 2 $\mathrm{mm}$ mesh sieve. Sediment $\mathrm{pH}$ and conductivity were analyzed by sediment-water suspension $(1: 10 \mathrm{w} / \mathrm{v}$ ratio $)$ with double distilled water from diluted (1:10 w/v ratio) air-dried sediment. Organic carbon (OC) percentage and cation exchange capacity (CEC) of sediment samples were analyzed following the methods adopted by Walkley and Black [23] and van Reeuwijk [24], respectively.

Plant samples were gently washed with deionized water, their root and shoot parts were separated, and they were dried at a

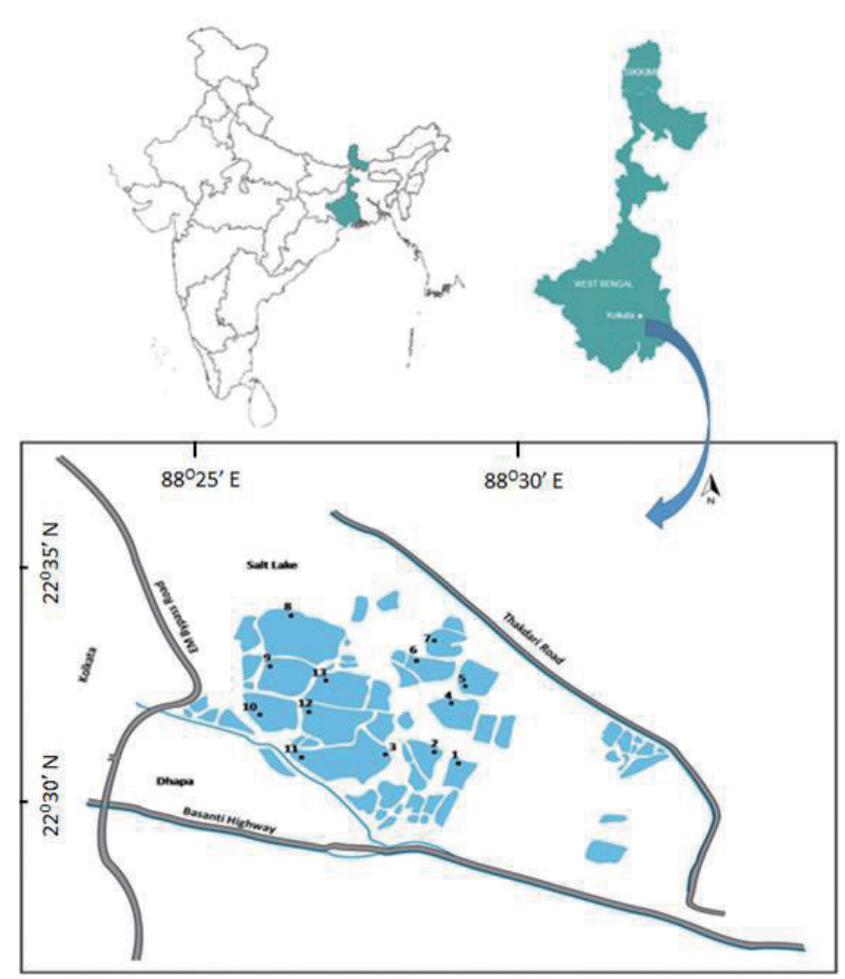

Figure 1. Location of the sampling sites. 
constant $60^{\circ} \mathrm{C}$ in a hot air oven for 24 hours. For the metal analysis, sediment samples were digested with $\mathrm{HNO}_{3}-\mathrm{HClO}_{4}$ following the procedure described by Chen and $\mathrm{Ma}$ [25], and plant samples were digested with aqua regia-hydrogen peroxide as per the method of Mondal et al. [26]. Metals were analyzed using an atomic absorption spectrometer (GBC Avanta, Dandenong, Victoria, Australia).

\section{Statistical Analysis}

Statistical analysis was performed using the SPSS version 16.0 (SPSS Inc., Chicago, IL, USA). The correlation significance level $(p<0.01$ and $p<0.05)$ between different sediment parameters and the concentration of metals is reported based on Pearson's correlation coefficients. Results are presented as the mean ( \pm standard deviation) $(\mathrm{n}=6)$.

\section{Results}

The concentrations of metals in water at 13 locations are presented in Table 1. The concentration of Cd ranged between 0.02 and $0.19 \mathrm{mg} / \mathrm{L}, \mathrm{Cu}$ was between 0.02 and $0.03 \mathrm{mg} / \mathrm{L}$, Mn varied between 0.12 and $3.23 \mathrm{mg} / \mathrm{L}$, and $\mathrm{Pb}$ was found in the range of $0.10-0.92 \mathrm{mg} / \mathrm{L}$. These results showed that the average concentrations of these metals in the water were in the order: $\mathrm{Mn}$ $(1.67 \pm 1.23)>\mathrm{Pb}(0.28 \pm 0.26)>\mathrm{Cu}(0.09 \pm 0.05)>\mathrm{Cd}$ $(0.02 \pm 0.01)$.

Physicochemical characteristics of sediment are recorded in Table 2. Sediment $\mathrm{pH}$ varied from 6.97 to 7.46 with an average of $7.21( \pm 0.32)$ indicating slightly alkaline nature. EC ranged between 193 and $578 \mu \mathrm{S} / \mathrm{cm}$ with an average of $338( \pm 124)$

Table 1. Concentrations of metals in water samples collected from the East Kolkata Wetlands

\begin{tabular}{lcccc}
\hline $\begin{array}{c}\text { Sampling } \\
\text { site }\end{array}$ & $\mathrm{Cd}$ & $\mathrm{Cu}$ & $\mathrm{Mn}$ & $\mathrm{Pb}$ \\
\hline 1 & $0.10 \pm 0.04$ & $0.03 \pm 0.00$ & $3.23 \pm 0.92$ & $0.45 \pm 0.13$ \\
2 & $0.19 \pm 0.07$ & $0.02 \pm 0.02$ & $2.79 \pm 0.77$ & $0.28 \pm 0.04$ \\
3 & $0.09 \pm 0.05$ & $0.02 \pm 0.02$ & $2.16 \pm 1.08$ & $0.16 \pm 0.03$ \\
4 & $0.09 \pm 0.03$ & $0.02 \pm 0.01$ & $1.82 \pm 0.73$ & $0.19 \pm 0.01$ \\
5 & $0.10 \pm 0.02$ & $0.02 \pm 0.02$ & $1.49 \pm 0.48$ & $0.10 \pm 0.02$ \\
6 & $0.06 \pm 0.05$ & $0.02 \pm 0.01$ & $0.53 \pm 0.07$ & $0.09 \pm 0.01$ \\
7 & $0.02 \pm 0.01$ & $0.02 \pm 0.00$ & $0.21 \pm 0.11$ & $0.16 \pm 0.02$ \\
8 & $0.09 \pm 0.02$ & $0.02 \pm 0.01$ & $0.12 \pm 0.03$ & $0.10 \pm 0.02$ \\
9 & $0.04 \pm 0.01$ & $0.02 \pm 0.01$ & $1.14 \pm 0.33$ & $0.19 \pm 0.07$ \\
10 & $0.04 \pm 0.02$ & $0.02 \pm 0.01$ & $0.16 \pm 0.02$ & $0.11 \pm 0.02$ \\
11 & $0.10 \pm 0.04$ & $0.02 \pm 0.02$ & $2.84 \pm 1.05$ & $0.71 \pm 0.15$ \\
12 & $0.13 \pm 0.02$ & $0.02 \pm 0.01$ & $2.81 \pm 0.93$ & $0.14 \pm 0.01$ \\
13 & $0.11 \pm 0.06$ & $0.02 \pm 0.01$ & $2.40 \pm 1.09$ & $0.92 \pm 0.15$
\end{tabular}

Values are presented as mean \pm standard deviation.

Unit: $\mathrm{mg} / \mathrm{L}$

Cd, cadmium; Cu, copper; Mn, Manganese; Pb, lead. $\mu \mathrm{S} / \mathrm{cm}$. OC percentage and CEC were recorded between 0.95 and $3.66 \%$ and 0.26 and $1.91 \mathrm{meq}$ of $\mathrm{Na} / 100 \mathrm{~g}$ of soil, respectively. The average percentage of $\mathrm{OC}$ in the sediment was high $(2.40 \pm 1.17 \%)$. The average CEC was $1.14( \pm 0.52)$ meq of $\mathrm{Na} / 100 \mathrm{~g}$ of soil.

The concentrations of metals in sediment samples are given in Table 3. Cd concentration in the sediment ranged between 1.59 and $8.11 \mathrm{mg} / \mathrm{kg}$, Cu between 19.4 and $48.5 \mathrm{mg} / \mathrm{kg}, \mathrm{Mn}$ between 43 and $280 \mathrm{mg} / \mathrm{kg}$, and $\mathrm{Pb}$ was recorded between 10.8 and $32.6 \mathrm{mg} / \mathrm{kg}$.

The correlations between different sediment parameters and metals are given in Table 4. The $\mathrm{pH}$ and EC did not show significant correlations with other parameters. The OC percentage showed a strongly significant correlation $(p<0.001)$ with CEC $(\mathrm{r}=0.819), \mathrm{Mn}(\mathrm{r}=0.771)$, and $\mathrm{Pb}(\mathrm{r}=0.832)$. CEC also showed strong positive correlations with $\mathrm{Cu}(\mathrm{r}=0.721), \mathrm{Mn}$ $(\mathrm{r}=0.713)$, and $\mathrm{Pb}(\mathrm{r}=0.788)$. In addition, correlations between OC percentage and $\mathrm{Cu}(\mathrm{r}=0.628)$, OC percentage and $\mathrm{Cd}(\mathrm{r}=0.559)$, and CEC and Cd $(\mathrm{r}=0.625)$ were significant at the $p<0.05$ level.

The concentrations of $\mathrm{Cu}, \mathrm{Cd}, \mathrm{Mn}$, and $\mathrm{Pb}$ in plant roots and shoots are given in Table 5. In C. esculenta, the average $\mathrm{Cd}, \mathrm{Cu}$, $\mathrm{Mn}$, and $\mathrm{Pb}$ concentrations were $3.72( \pm 1.90), 25.3( \pm 15.0)$, $409( \pm 210)$ and $22.8( \pm 10.2) \mathrm{mg} / \mathrm{kg}$ dry weight (DW) in shoot, respectively; and $4.16( \pm 1.98), 28.6( \pm 8.77), 495( \pm 119)$ and $25.5( \pm 11.6) \mathrm{mg} / \mathrm{kg}$ DW in root, respectively. In S. articulatus, average $\mathrm{Cd}, \mathrm{Cu}, \mathrm{Mn}$ and $\mathrm{Pb}$ concentrations were 5.95 ( \pm 3.07 ), $56.0( \pm 16.5), 410( \pm 111)$ and $26.2( \pm 13.7) \mathrm{mg} / \mathrm{kg} \mathrm{DW}$ in shoot, respectively; and $7.00( \pm 1.66), 68.6( \pm 22.7), 840( \pm 349)$ and $27.3( \pm 14.8) \mathrm{mg} / \mathrm{kg}$ DW in root, respectively.

Table 2. Physicochemical properties of sediment samples collected from the East Kolkata Wetlands

\begin{tabular}{llllc}
\hline $\begin{array}{c}\text { Sampling } \\
\text { site }\end{array}$ & \multicolumn{1}{c}{$\mathrm{pH}$} & $\mathrm{EC}(\mathrm{\mu S} / \mathrm{cm})$ & \multicolumn{1}{c}{ OC $(\%)$} & $\begin{array}{c}\text { CEC (meq of } \\
\mathrm{Na} / 100 \mathrm{~g} \text { of soil) }\end{array}$ \\
\hline 1 & $7.05 \pm 0.10$ & $290 \pm 53$ & $2.61 \pm 1.14$ & $1.28 \pm 0.55$ \\
2 & $7.25 \pm 0.26$ & $309 \pm 95$ & $3.22 \pm 1.05$ & $1.45 \pm 0.48$ \\
3 & $7.30 \pm 0.29$ & $311 \pm 109$ & $2.05 \pm 0.90$ & $1.12 \pm 0.28$ \\
4 & $7.46 \pm 0.22$ & $247 \pm 64$ & $2.75 \pm 1.14$ & $1.43 \pm 0.48$ \\
5 & $7.35 \pm 0.17$ & $430 \pm 70$ & $2.53 \pm 1.60$ & $1.28 \pm 0.28$ \\
6 & $7.25 \pm 0.30$ & $223 \pm 33$ & $1.40 \pm 0.40$ & $0.64 \pm 0.28$ \\
7 & $7.25 \pm 0.08$ & $355 \pm 112$ & $2.41 \pm 1.76$ & $1.12 \pm 0.28$ \\
8 & $7.02 \pm 0.63$ & $224 \pm 120$ & $0.95 \pm 0.73$ & $0.65 \pm 0.26$ \\
9 & $7.10 \pm 0.83$ & $374 \pm 93$ & $1.93 \pm 1.34$ & $0.80 \pm 0.28$ \\
10 & $7.24 \pm 0.56$ & $578 \pm 87$ & $1.28 \pm 0.71$ & $0.42 \pm 0.14$ \\
11 & $7.37 \pm 0.06$ & $476 \pm 60$ & $3.66 \pm 1.06$ & $1.59 \pm 0.28$ \\
12 & $6.97 \pm 0.41$ & $380 \pm 49$ & $2.83 \pm 1.03$ & $1.44 \pm 0.47$ \\
13 & $7.11 \pm 0.38$ & $193 \pm 56$ & $3.61 \pm 1.22$ & $1.62 \pm 0.25$ \\
\hline
\end{tabular}

Values are presented as mean \pm standard deviation.

EC, electrical conductivity; OC, organic carbon; CEC, cation exchange capacity; $\mathrm{Na}$, sodium. 
BCF and TF of the two plants C. esculenta and S. articulatusare given in Table 6. This study showed that in C. esculenta, BCF for $\mathrm{Cd}, \mathrm{Cu}, \mathrm{Mn}$ and $\mathrm{Pb}$ was 1.10 ( \pm 0.65$), 1.14$ ( \pm 0.52$), 2.01$ $( \pm 0.84)$ and $1.04( \pm 0.47)$, respectively; and in S. articulatus was 1.40 ( \pm 0.88$), 1.79( \pm 0.94), 2.49( \pm 1.04)$ and $1.35( \pm 1.18)$, respectively; $\mathrm{TF}$ for $\mathrm{Cd}, \mathrm{Cu}, \mathrm{Mn}$, and $\mathrm{Pb}$ was $0.67( \pm 0.50), 0.69$ $( \pm 0.28), 0.88( \pm 0.41)$ and $0.59( \pm 0.25)$, respectively in C. esculenta, and $1.03( \pm 0.50), 1.10( \pm 0.61), 1.14( \pm 0.65)$ and 0.78 $( \pm 0.28)$, respectively in S. articulatus.

\section{Discussion}

Metal uptake by plants depends on $\mathrm{pH}$, organic matter and CEC of the sediment [12]. $\mathrm{Cu}$ and $\mathrm{Mn}$ are the essential elements for plant growth, whereas $\mathrm{Cd}$ and $\mathrm{Pb}$ are toxic metals to plants. According to Kabata-Pendias and Pendias [27], 60-125 $\mathrm{mg} / \mathrm{kg}$ of $\mathrm{Cu}, 70-400 \mathrm{mg} / \mathrm{kg}$ of $\mathrm{Zn}, 100-400 \mathrm{mg} / \mathrm{kg}$ of $\mathrm{Pb}$ and $3-8 \mathrm{mg} / \mathrm{kg}$ of $\mathrm{Cd}$, based on total fractions in the soil, would be considered toxic to plants. The Cd content in the EKW sedi-

Table 3. Metal concentrations on a dry weight basis of sediment samples collected from the East Kolkata Wetlands

\begin{tabular}{lllll}
\hline Sampling site & \multicolumn{1}{c}{$\mathrm{Cd}$} & \multicolumn{1}{c}{$\mathrm{Cu}$} & \multicolumn{1}{c}{$\mathrm{Mn}$} & \multicolumn{1}{c}{$\mathrm{Pb}$} \\
\hline 1 & $3.94 \pm 1.33$ & $36.5 \pm 16.4$ & $251 \pm 2$ & $26.0 \pm 12.8$ \\
2 & $7.71 \pm 1.82$ & $38.7 \pm 15.5$ & $246 \pm 28$ & $32.2 \pm 10.2$ \\
3 & $3.31 \pm 1.89$ & $28.5 \pm 4.8$ & $220 \pm 39$ & $16.7 \pm 8.1$ \\
4 & $2.93 \pm 1.34$ & $30.3 \pm 12.1$ & $236 \pm 69$ & $27.9 \pm 11.4$ \\
5 & $2.84 \pm 0.48$ & $31.7 \pm 3.5$ & $217 \pm 2$ & $21.2 \pm 11.6$ \\
6 & $2.20 \pm 0.42$ & $23.9 \pm 6.1$ & $198 \pm 2$ & $12.3 \pm 6.0$ \\
7 & $1.74 \pm 0.23$ & $28.7 \pm 6.9$ & $189 \pm 43$ & $21.5 \pm 10.9$ \\
8 & $2.15 \pm 0.49$ & $20.7 \pm 3.5$ & $43 \pm 17$ & $10.8 \pm 1.4$ \\
9 & $1.59 \pm 0.05$ & $19.4 \pm 2.7$ & $173 \pm 25$ & $19.4 \pm 10.6$ \\
10 & $2.59 \pm 0.34$ & $23.9 \pm 9.0$ & $135 \pm 21$ & $15.5 \pm 6.7$ \\
11 & $3.79 \pm 1.33$ & $48.5 \pm 14.1$ & $280 \pm 53$ & $33.3 \pm 12.2$ \\
12 & $4.83 \pm 0.42$ & $26.9 \pm 4.7$ & $227 \pm 37$ & $25.2 \pm 8.8$ \\
13 & $8.11 \pm 2.10$ & $31.1 \pm 1.4$ & $250 \pm 35$ & $32.6 \pm 10.7$ \\
\hline
\end{tabular}

Values are presented as mean \pm standard deviation. Unit: $\mathrm{mg} / \mathrm{kg}$.

Cd, cadmium; Cu, copper; Mn, manganese; Pb, lead. ment exceeds these ranges, indicating that plants in these wetlands are under stress. Chattopadhyay et al. [14] estimated the metal concentration in sediment of the EKW and found that $\mathrm{Cu}, \mathrm{Mn}$, and $\mathrm{Pb}$ concentrations were in the range of 0.01-1.49 $\mathrm{mg} / \mathrm{kg}, 0.61-2.25 \mathrm{mg} / \mathrm{kg}$ and $0.25-1.46 \mathrm{mg} / \mathrm{kg}$, respectively. High concentrations of $\mathrm{Cu}(210.0 \pm 17.0 \mathrm{mg} / \mathrm{kg}), \mathrm{Mn}$ $(552.0 \pm 14.9 \mathrm{mg} / \mathrm{kg})$ and $\mathrm{Pb}(166.0 \pm 15.3 \mathrm{mg} / \mathrm{kg})$ were reported in the sediment of the EKW by Chatterjee et al. [3]. Tang et al. [28] reported five times lower Cd level, 2.5 times lower $\mathrm{Pb}$ level and almost 1.5 times lower $\mathrm{Cu}$ level in wetland sediment of eastern China compared to the present study. Hu et al. [29] also reported a lower $\mathrm{Cd}$ level but higher $\mathrm{Pb}$ level in sediment of Dongting Lake. Therefore, the present study revealed that the EKW is under ill effects of heavy metal pollution. Higher metal concentrations were observed in this study in comparison to previous studies in the area due to differences in sampling location, as previous studies collected the sediment from wastewater carrying bottom sediment. The average metal concentration in the present study was, in order from highest to lowest: $\mathrm{Mn}(205.0 \pm 65.5 \mathrm{mg} / \mathrm{kg})>\mathrm{Cu}(29.9 \pm 10.2 \mathrm{mg} / \mathrm{kg})>\mathrm{Pb}$ $(22.7 \pm 10.3 \mathrm{mg} / \mathrm{kg})>\mathrm{Cd}(3.67 \pm 2.22 \mathrm{mg} / \mathrm{kg})$. A similar trend in the gradient of metal concentrations was also reported in sediment from different locations within the same wetland [3]. Metal undergoes physical, chemical and biological changes after discharging into the aquatic environment and usually binds with the particulate matter, ultimately settling down in the sediment [30]. Higher metal concentration in sediment than in water observed in the present study was also explained by previous research $[5,12,30]$.

Strong positive correlations between OC and the heavy metals indicated regulated movement of heavy metals in the wetland environment as $\mathrm{OC}$ acts as a major sink for heavy metals (i.e., $\mathrm{Cd}$, chromium, $\mathrm{Cu}$, nickel, $\mathrm{Pb}$, and $\mathrm{Zn}$ ) due to its strong complexing capacity for metallic contaminants [31], which can also be related to the strong, positive correlation between heavy metals and sediment CEC. Additionally, this indicates that heavy

Table 4. Correlation matrix (Pearson's correlation coefficients) of sediment properties and metals

\begin{tabular}{|c|c|c|c|c|c|c|c|c|}
\hline & $\mathrm{pH}$ & EC & $\mathrm{OC}$ & CEC & $\mathrm{Cd}$ & $\mathrm{Cu}$ & $\mathrm{Mn}$ & $\mathrm{Pb}$ \\
\hline $\mathrm{pH}$ & 1 & & & & & & & \\
\hline EC & 0.199 & 1 & & & & & & \\
\hline OC & 0.182 & -0.043 & 1 & & & & & \\
\hline CEC & 0.124 & -0.162 & $0.819^{\star \star}$ & 1 & & & & \\
\hline $\mathrm{Cd}$ & -0.084 & -0.175 & $0.559^{\star}$ & $0.625^{*}$ & 1 & & & \\
\hline $\mathrm{Cu}$ & 0.283 & 0.103 & $0.628^{*}$ & $0.721^{\star \star}$ & 0.401 & 1 & & \\
\hline $\mathrm{Mn}$ & 0.267 & 0.088 & $0.771^{\star \star}$ & $0.713^{\star \star}$ & 0.397 & $0.627^{*}$ & 1 & \\
\hline $\mathrm{Pb}$ & 0.127 & 0.035 & $0.832^{\star \star}$ & $0.788^{\star \star}$ & $0.652^{*}$ & $0.669^{\star}$ & $0.725^{\star \star}$ & 1 \\
\hline
\end{tabular}

$\mathrm{EC}$, electrical conductivity; OC, organic carbon percentage; CEC, cation exchange capacity; Cd, cadmium; Cu, copper; Mn, manganese; $\mathrm{Pb}$, lead. ${ }^{\star} p<0.05,{ }^{\star *} p<0.01$. 
metals in the wetland are originating from internal sources such as the predominant rocks [32]. The higher correlation between heavy metals observed in the present study can be explained by the salinity of the wetland. The lack of significant correlations between heavy metals and sediment $\mathrm{pH}$ and $\mathrm{EC}$ might be due to the narrow range of $\mathrm{pH}$ in the samples. Metal mobility is hindered by the slightly alkaline $\mathrm{pH}$ [32] and the lower mobility would favor metal accumulation in the soil [33].

The concentrations of $\mathrm{Cu}, \mathrm{Cd}, \mathrm{Mn}$, and $\mathrm{Pb}$ in plant roots and shoots showed that roots accumulate greater concentrations than shoots, indicating high plant availability of the substrate metals as well as their limited mobility once inside the plant. The results are also supported by the findings of Outridge and Noller [34]. Tolerant species try to restrict the transfer of metals during sediment-root and root-shoot transfer $[12,35]$. These results showed that in general, the accumulation of metals was higher in root than shoot, and also revealed that the capacity for metal accumulation in S. articulatus was higher than in C. esculenta. The $\mathrm{Cd}$ concentration in both plant species examined in this study was within the range found in contaminated plants i.e., $5-30 \mathrm{mg} /$ $\mathrm{kg}$; and it indicates that $\mathrm{S}$. articulatus was more efficient accumulate or than C. esculenta [27]. Likewise, the Cd concentration was also above the toxic level i.e., $20 \mathrm{mg} / \mathrm{kg}$, as indicated by Borkert et al. [36], and S. articulatus showed a higher value than C. esculenta, indicating that $S$. articulatus was more good accumulator. $\mathrm{Pb}$ concentration in the plant parts was lower than the phytotoxic value $27 \mathrm{mg} / \mathrm{kg}$ in the case of C. esculenta, but higher in $S$. articulates [37], again implying that $S$. articulatus is more competent in accumulating the metals. Alloway et al. [38] also reported that metal bioaccumulation in plants varies from species to species. Uptake of metals by plants from soil generally occurs either passively, through the mass flow of water into the roots, or by ac- tive transport through the plasma membrane of root epidermal cells [12]. The plant is able to accumulate greater amounts of metal than is present in the surrounding medium [39]. The order of metal accumulation in these two plants both in shoots and roots was $\mathrm{Mn}>\mathrm{Cu}>\mathrm{Pb}>\mathrm{Cd}$.

The BCF of a plant indicates it sability to accumulate metal from the sediment in its shoots, whereas the ability of a plant to translocate it from root to shoot is expressed by the TF. These two factors are used to estimate the phytoremediation potential of a plant species [12]. Both BCF and TF values were higher in S. articulatus than C. esculenta. Ma et al. [10] reported that if a plant has TF and BCF values greater than 1, then it is a good accumulator plant. Accordingly, in the present study, S. articulatus acts as a better accumulator than C. esculenta due to its higher $\mathrm{TF}$ and its BCF being greater than 1 . Higher accumulation of heavy metals in plants indicates lower concentrations of metal, both in the water and the sediment of the wetland. Therefore, $S$. articulatus acts as a greater phytoremediator of heavy metals than C. esculenta due to its higher translocation ability. Ma et al. $[10]$ also reported that $\mathrm{TF}$ and $\mathrm{BCF}$ were greater than 1 in fern species for arsenic. In addition, the order of $\mathrm{BCF}$ and $\mathrm{TF}$ in both of the two plants studied here was: $\mathrm{Mn}>\mathrm{Cu}>\mathrm{Cd}>\mathrm{Pb}$. Phytostabilization is a property of plants that reduces the mobility of metal ions in the sediment. Through this process, plants bind the metal in the root or help in precipitation within the rhizosphere. According to Miller [40], plants with greater root biomass have the ability to immobilize contaminants by holding them in their roots. As a result, the leaching of metal to groundwater can be prevented, and the contamination of the food chain by metals can also be reduced [12]. Yoon et al. [12] stated that plants with high BCF but low TF can also be used for phytostabilization. In this study, both plant species examined are

Table 5. Concentrations on a dry weight basis of cadmium (Cd), copper $(\mathrm{Cu})$, manganese $(\mathrm{Mn})$ and lead $(\mathrm{Pb})$ in shoot and root of Colocasi aesculenta and Scirpus articulatus

\begin{tabular}{|c|c|c|c|c|c|c|c|c|}
\hline \multirow{2}{*}{ Plant name } & \multicolumn{2}{|c|}{$\mathrm{Cd}$} & \multicolumn{2}{|c|}{$\mathrm{Cu}$} & \multicolumn{2}{|c|}{$\mathrm{Mn}$} & \multicolumn{2}{|c|}{$\mathrm{Pb}$} \\
\hline & Shoot & Root & Shoot & Root & Shoot & Root & Shoot & Root \\
\hline C. sculenta & $3.72 \pm 1.90$ & $4.16 \pm 1.98$ & $25.3 \pm 15.0$ & $28.6 \pm 8.8$ & $409 \pm 210$ & $495 \pm 119$ & $22.8 \pm 10.2$ & $25.5 \pm 11.6$ \\
\hline S. articulatus & $5.95 \pm 3.07$ & $7.00 \pm 1.66$ & $56.0 \pm 16.5$ & $68.6 \pm 22.7$ & $410 \pm 111$ & $840 \pm 349$ & $26.2 \pm 13.7$ & $27.3 \pm 14.8$ \\
\hline
\end{tabular}

Values are presented as mean \pm standard deviation.

Unit: $\mathrm{mg} / \mathrm{kg}$.

Table 6. Bioaccumulation factor (BCF) and translocation factor (TF) of cadmium (Cd), copper (Cu), manganese (Mn) and lead (Pb) of Colocasia esculenta and Scirpus articulatus

\begin{tabular}{|c|c|c|c|c|c|c|c|c|}
\hline \multirow{2}{*}{ Plant name } & \multicolumn{2}{|c|}{$\mathrm{Cd}$} & \multicolumn{2}{|c|}{$\mathrm{Cu}$} & \multicolumn{2}{|c|}{$\mathrm{Mn}$} & \multicolumn{2}{|c|}{$\mathrm{Pb}$} \\
\hline & BCF & TF & $\mathrm{BCF}$ & TF & $\mathrm{BCF}$ & TF & BCF & TF \\
\hline C. sculenta & $1.10 \pm 0.65$ & $0.67 \pm 0.50$ & $1.14 \pm 0.52$ & $0.69 \pm 0.28$ & $2.01 \pm 0.84$ & $0.88 \pm 0.41$ & $1.04 \pm 0.47$ & $0.59 \pm 0.25$ \\
\hline S. articulatus & $1.40 \pm 0.88$ & $1.03 \pm 0.50$ & $1.79 \pm 0.94$ & $1.10 \pm 0.61$ & $2.49 \pm 1.04$ & $1.14 \pm 0.65$ & $1.35 \pm 1.18$ & $0.78 \pm 0.27$ \\
\hline
\end{tabular}

Values are presented as mean \pm standard deviation. 
suitable for phytostabilization due to their comparatively high $\mathrm{BCF}$ and low TF values. In particular, here C. esculenta has more potential for phytostabilization than S. articulatus and this may be due to differences in their root structure system. This study suggests that these two plants could be utilized for natural attenuation of metals in contaminated soil.

\section{Acknowledgements}

The authors would like to thank the University Grants Commission for financial assistance, and would also like to acknowledge the Head, Department of Environmental Science, The University of Burdwan, Burdwan, West Bengal, India for providing the laboratory facilities and library facilities during the course of research.

\section{Conflict of interest}

The authors have no conflicts of interest associated with material presented in this paper.

\section{ORCID}

Amina Khatun http://orcid.org/0000-0003-1005-7206

Sandipan Pal http://orcid.org/0000-0003-3552-1722

Aloke Kumar Mukherjee http://orcid.org/0000-0002-2309-0681

Palas Samanta http://orcid.org/0000-0001-9369-7502

Subinoy Mondal http://orcid.org/0000-0001-6212-2423

Debraj Kole http://orcid.org/0000-0002-3083-8168

Priyanka Chandra http://orcid.org/0000-0002-8848-0146

Apurba Ratan Ghosh http://orcid.org/0000-0003-1454-7720

\section{References}

1. Spiegel SJ, Farmer JK, Garver SR. Heavy metal concentrations in municipal wastewater treatment plant sludge. Bull Environ Contam Toxicol 1985;35(1):38-43.

2. Hanay O, Hasar H, Kocer NN, Aslan S. Evaluation for agricultural usage with speciation of heavy metals in a municipal sewage sludge. Bull Environ Contam Toxicol 2008;81(1):42-46.

3. Chatterjee S, Chetia M, Singh L, Chattopadhyay B, Datta S, Mukhopadhyay SK. A study on the phytoaccumulation of waste elements in wetland plants of a Ramsar site in India. Environ Monit Assess 2011;178(1-4):361-371.

4. Virha R, Biswas AK, Kakaria VK, Qureshi TA, Borana K, Malik N. Seasonal variation in physicochemical parameters and heavy metals in water of Upper Lake of Bhopal. Bull Environ Contam Toxicol 2011;86(2):168-174.

5. Milošković A, Branković S, Simić V, Kovačević S, Ćirković M, Manojlović $\mathrm{D}$. The accumulation and distribution of metals in wa- ter, sediment, aquatic macrophytes and fishes of the Gruža Reservoir, Serbia. Bull Environ Contam Toxicol 2013;90(5):563-569.

6. Tuurala H, Soivio A. Structural and circulatory changes in the secondary lamellae of salmo gairdneri gills after sublethal exposures to dehydroabietic acid and zinc. Aquat Toxicol 1982;2(1):21-29.

7. Patel JM, Bahadur A. Histopathological alterations in Catla catla induced by chronic exposure of copper ions. J Cell Tissue Res 2010; 10(3):2365-2370.

8. Prusty BA, Azeez PA, Jagadeesh EP. Alkali and transition metals in macrophytes of a wetland system. Bull Environ Contam Toxicol 2007;78(5):405-410.

9. Prasad SN, Ramachandra TV, Ahalya N, Sengupta T, Kumar A, Tiwar AK, et al. Conservation of wetlands of India: a review. Trop Ecol 2002;43(1):173-186.

10. Ma LQ, Komar KM, Tu C, Zhang W, Cai Y, Kennelley ED. A fern that hyperaccumulates arsenic. Nature 2001;409(6820):579.

11. Cunningham SD, Berti WR. Remediation of contaminated soils with green plants: an overview. In Vitro Cell Dev Biol Plant 1993; 29(4):207-212.

12. Yoon J, Cao X, Zhou Q, Ma LQ. Accumulation of $\mathrm{Pb}, \mathrm{Cu}$, and $\mathrm{Zn}$ in native plants growing on a contaminated Florida site. Sci Total Environ 2006;368(2-3):456-464.

13. Mazumdar K, Das S. Phytoremediation of $\mathrm{Pb}, \mathrm{Zn}, \mathrm{Fe}$, and $\mathrm{Mg}$ with 25 wetland plant species from a paper mill contaminated site in North East India. Environ Sci Pollut Res Int 2015;22(1):701-710.

14. Chattopadhyay B, Chatterjee A, Mukhopadhyay SK. Bioaccumulation of metals in the East Calcutta wetland ecosystem. Aquat Ecosyst Health Manag 2002;5(2):191-203.

15. Nandi S, Srivastava C, Agarwal KM. Heavy metal concentration in surface water of East Kolkata wetland. Indian J Public Health Res Dev 2013;4(4):227-230.

16. Sarkar S, Ghosh PB, Sil AK, Saha T. Heavy metal pollution assessment through comparison of different indices in sewage-fed fishery pond sediments at East Kolkata Wetland, India. Environ Earth Sci 2011;63(5):915-924.

17. Chatterjee S, Chattopadhyay B, Mukhopadhyay SK. Trace metal distribution in tissues of cich-lids (Oreochromis niloticus and $\mathrm{O}$. mossambicus) collected from wastewater-fed fishponds in East Calcutta Wetlands, a Ramsar site. Acta Ichthyol Piscat 2006;36(2): 119-125.

18. Kumar B, Mukherjee DP, Kumar S, Mishra M, Prakash D, Singh SK, et al. Bioaccumulation of heavy metals in muscle tissue of fishes from selected aquaculture ponds in east Kolkata wetlands. Ann Biol Res 2011;2(5):125-134.

19. Maiti P, Banerjee S. Fate of metals in fish under variable sewage input in fish ponds. Int J Sci Res Publ 2012;2(6):1-13.

20. Nath S, Bhoumik M. Levels of toxic metals in edible fish from a wetland of India. Int J Environ Sci 2013;3(5):1509-1515.

21. Chatterjee S, Chattopadhyay B, Mukhopadhyay SK. Monitoring waste metal pollution at Ganga estuary via the East Calcutta Wetland areas. Environ Monit Assess 2010;170(1-4):23-31.

22. American Public Health Association. Standard methods for the examination of water and wastewater. 10th ed. Washington, DC: American Public Health Association; 2000.

23. Walkley A, Black IA. An examination of the Degtjareff method for determining soil organic matter, and a proposed modification of 
the chromic acid titration method. Soil Sci 1934;37(1):29-38.

24. van Reeuwijk LP. Procedure for soil analysis; 2002 [cited 2016 Oct 10]. Available from: http://www.isric.org/isric/webdocs/docs/ ISRIC_TechPap09_2002.pdf.

25. Chen $\mathrm{M}, \mathrm{Ma} \mathrm{LQ}$. Comparison of three aqua regia digestion methods for twenty Florida soils. Soil Sci Soc Am J 2001;65(2):491-499.

26. Mondal BC, Das D, Das AK. Preconcentration and separation of copper, zinc and cadmium by the use of 6-mercapto purinylazo resin and their application in microwave digested certified biological samples followed by AAS determination of the metal ions. J Trace Elem Med Biol 2002;16(3):145-148.

27. Kabata-Pendias A, Pendias H. Trace elements in soils and plants. 3rd ed. Boca Raton: CRC Press; 2000.

28. Tang W, Shan B, Zhang W, Zhang H, Wang L, Ding Y. Heavy metal pollution characteristics of surface sediments in different aquatic ecosystems in eastern China: a comprehensive understanding. PLoS One 2014;9(9):e108996.

29. Hu C, Deng ZM, Xie YH, Chen XS, Li F. The risk assessment of sediment heavy metal pollution in the East Dongting Lake Wetland. J Chem 2015;2015:835487.

30. Rai PK. Heavy metals in water, sediments and wetland plants in an aquatic ecosystem of tropical industrial region, India. Environ Monit Assess 2009; 158(1-4):433-457.

31. Du Laing G, Rinklebe J, Vandecasteele B, Meers E, Tack FM. Trace metal behaviour in estuarine and riverine floodplain soils and sediments: a review. Sci Total Environ 2009;407(13):3972-3985.

32. Kumpiene J, Lagerkvist A, Maurice C. Stabilization of As, Cr, Cu,
$\mathrm{Pb}$ and $\mathrm{Zn}$ in soil using amendments--a review. Waste Manag 2008; 28(1):215-225.

33. Kashem MA, Singh BR. Metal availability in contaminated soils: II. Uptake of Cd, $\mathrm{Ni}$ and $\mathrm{Zn}$ in rice plants grown under flooded culture with organic matter addition. Nutr Cycl Agroecosys 2001; 61(3):257-266.

34. Outridge PM, Noller BN. Accumulation of toxic trace elements by freshwater vascular plants. Rev Environ Contam Toxicol 1991; 121:1-63.

35. Ahmad A, Ghufran R, Zularisam AW. Phytosequestration of metals in selected plants growing on a contaminated Okhla industrial areas, Okhla, New Delhi, India. Water Air Soil Pollut 2011;217(1):255266.

36. Borkert CM, Cox FR, Tucker MR. Zinc and copper toxicity in peanut, soybean, rice, and corn in soil mixtures. Commun Soil Sci Plant Anal 1998;29(19-20):2991-3005.

37. Beckett PH, Davis RD. Upper critical levels of toxic elements in plants. New Phytol 1977;79(1):95-106.

38. Alloway BJ, Jackson AP, Morgan H. The accumulation of cadmium by vegetables grown on soils contaminated from a variety of sources. Sci Total Environ 1990;91:223-236.

39. Mishra VK, Upadhyay AR, Pandey SK, Tripathi BD. Concentrations of heavy metals and aquatic macrophytes of Govind Ballabh Pant Sagar an anthropogenic lake affected by coal mining effluent. Environ Monit Assess 2008;141(1-3):49-58.

40. Miller RR. Phytoremediation; 1996 [cited 2016 Oct 10]. Available from: https://clu-in.org/download/toolkit/phyto_o.pdf. 